\title{
THE TRANSLATION OF PHRASAL VERBS IN THE SUBTITLING FROM ENGLISH TO PORTUGUESE IN THE SERIES BEWITCHED
}

\author{
Cristina Pasquetti Massutti ${ }^{1}$ \\ Sabrina Bonqueves Fadanelli ${ }^{2}$
}

\begin{abstract}
This study aims to determine how the phrasal verbs used in English in the TV series Bewitched convey the same meanings of the translation to Portuguese in the subtitles. The research follows the model of Vinay and Darbelnet (1989) with focus on part of their theory called Oblique Translation. The study is exploratory and the episodes of Bewitched series selected were from the first and the last season, aiming at comparing the English phrasal verbs with the respective translation in the subtitles to Portuguese. The software AntConc was used to locate phrasal verbs through scripts; the software Notepad++ was used to compare the English and Portuguese versions; and the Excel software enabled the researcher to organize the data found. The results are in accordance to Vinay and Darbelnet's theory $(1989,2004)$, emphasizing that the phrasal verbs with the particles up, away and off found in the corpus were translated using the processes of Oblique Translation instead of literal translation.
\end{abstract} Keywords: Phrasal Verbs. Oblique Translation. Subtitling. Corpus. Bewitched Series.

\section{A TRADUÇÃO DE PHRASAL VERBS NAS LEGENDAS DO INGLÊS PARA O PORTUGUÊS NA SÉRIE $A$ FEITICEIRA}

\begin{abstract}
Resumo
Este estudo tem como objetivo determinar como os verbos frasais utilizados em inglês na série de TV A Feiticeira transmitem o mesmo significado da tradução para o português nas legendas. A pesquisa segue o modelo de Vinay e Darbelnet $(1989,2004)$, com foco em parte de suas teorias denominada Tradução Oblíqua. O estudo é exploratório e os episódios da série A Feiticeira selecionados foram da primeira e da última temporada, com o objetivo de comparar verbos frasais em Inglês com a respectiva tradução nas legendas para o português. O software AntConc foi utilizado para localizar verbos frasais por meio de scripts; o software Notepad ++ foi utilizado para comparar as versões em inglês e português; e o software Excel permitiu a organização dos dados encontrados. Os resultados são mostrados de acordo com a teoria de Vinay e Darbelnet $(1989,2004)$, enfatizando que os phrasal verbs com as partes up, away e off encontrados no corpus foram traduzidos usando os processos da Tradução Oblíqua, e não a tradução literal.
\end{abstract}

Palavras-chave: Verbos frasais. Tradução Oblíqua. Legendagem. Corpus. Série A feiticeira.

\section{INTRODUCTION}

\footnotetext{
1 Universidade de Caxias do Sul (UCS), Caxias do Sul - Rio Grande de Sul - Brasil. E-mail: cris_massutti@yahoo.com.br.

${ }^{2}$ Universidade de Caxias do Sul (UCS), Caxias do Sul - Rio Grande de Sul - Brasil. E-mail: sbfadane@ucs.br.
} 


\section{Linguagens - Revista de Letras, Artes e Comunicação - ISSN 1981-9943 \\ Blumenau, v. 13, n. 2, p. 289-300, maio/ago. 2019 \\ DOI: http://dx.doi.org/10.7867/1981-9943.2019v13n2p289-300}

There are many languages in the world, each one with its own particularities. For people who speak Portuguese as a first language, the use of phrasal verbs when learning English as a foreign language may sometimes be challenging to understand because this type of structure does not behave like any other structure in Portuguese. According to the Talmyan typology (TALMY, 1991; 2000), English is a Satellite-Framed language: most of the verbs expressing some sort of location idea operate and function around a "satellite" structure, in other words, a prepositional or adverbial particle; whereas Portuguese is part of the group of languages which are Verb-Framed, in which verbal structure regarding location is expressed through a single verbal unit. Phrasal verbs follow the Satellite-Framed structure, therefore their translation into Portuguese may fit what Cappelle and Loock (2017, p 4.) state: "linguistic characteristics of translated texts differ depending on the source language".

The study reported in this article is relevant because it deals with one specific challenge presented by the process of translation of phrasal verbs: the feature of translation subtitles and dubbing not always being shown the same as in the original dialogue. Even though there have been studies carried out regarding the translation of phrasal verbs in subtitles in different languages (VALENTINI, 2013; HASHEMIAN; AREZI, 2015; DEWI SATYA UTAMI, 2018, just to mention a few examples ), few studies have been found concentrating exclusively in how phrasal verbs are translated into Brazillian Portuguese in series or film subtitling. The search was conducted through Base de Dados da Capes. One example of study is the dissertation of Moraes (2015). Her study analyses how subtitlers attempt to maintain the cultural expression in the translation of collocational patterns, phrasal verbs included. Thus, this study aims at determining how the translation of English phrasal verbs in the first and the last season of the series Bewitched has been featured to the target language in Portuguese. It is an exploratory research study, encompassing the following methodological procedures: a) selecting the episodes to be analyzed in Bewitched in English (original) and in Portuguese (target language); b) using a Corpus Linguistics method to find the phrasal verbs in each episode through $A N T C O N C^{3}$ (ANTHONY, 2004) software; and c) carry out a case study to compare the original scripts with phrasal verbs with the translation in the subtitles to Portuguese, checking how they were translated: literally or using oblique translation, according to Vinay and Darbelnet's studies (1989; 2004).

The article is divided into the following parts: a) a description of the theory in which the study is grounded, followed by some key information regarding phrasal verbs and

\footnotetext{
${ }^{3}$ Available at https://www.laurenceanthony.net/software/antconc/. Access: April 2020.
} 


\section{Linguagens - Revista de Letras, Artes e Comunicação - ISSN 1981-9943 \\ Blumenau, v. 13, n. 2, p. 289-300, maio/ago. 2019 \\ DOI: http://dx.doi.org/10.7867/1981-9943.2019v13n2p289-300}

subtitling; b) the description of the methodology used; c) the analysis and discussion of the results; c) the concluding remarks.

\section{THE UNIVERSE OF TRANSLATION AND PHRASAL VERBS}

Campos (1986) argues that translation is an action of transferring from a language to another a specific written text. The original language can be referred to as "source language" and the final destination of the translation as "target language". Barbosa (1990) points out that there are two kinds of translation: literal translation, that is, word-by-word translation; and free translation, which is the transmission of the context itself.

Oustinoff (2011) elicits the three kinds of translation coined by Jakobson: Intralingual translation: a reformulation of the speech; Interlingual translation: the translation from a language to another, properly said, and Intersemiotic translation: an interpretation of the linguistic signs (words) using non-linguistic signs (images, for example).

This study will be grounded by the techniques proposed by Vinay and Darbelnet (1989; 2004), working with Interlingual translation. According to Vinay and Darbelnet (1989; 2004), there are two axes in which the translation can be distributed: direct (literal) translation and oblique translation (not literal or free). Direct translation implies that the isolated words in the original language are translated one by one into the target language. It should only be used if the translation has the same meaning as in the original language. That may also be the case where the original language may borrow some expressions of the translated language when there is no equivalence (BARBOSA, 1990).

Oblique translation, on the other hand, makes use of a number of resources that assist in the process of achieving a better result in the translating process (VINAY; DARBELNET, 1989; 2004): Transposition: replaces one word class with another, without altering the semantic content of the sentence. However, stylistically, it may cause a change in what Vinay and Darbelnet call 'value': the effect the register and the genre have on the choices of the translator. For example: the sentence in Portuguese $O$ assunto interessa a todos nós ${ }^{4}$ may be translated as the subject interests all of us or the subject is of interest to all of us.

After, we have Modulation: changes the point of view of the construction of a clause or phrase; used when a translation, even if seeming appropriate in grammatical terms, is considered unsuitable or awkward in the target language. For example, the sentence in

\footnotetext{
${ }^{4}$ All the examples were created by the authors.
} 


\section{Linguagens - Revista de Letras, Artes e Comunicação - ISSN 1981-9943 \\ Blumenau, v. 13, n. 2, p. 289-300, maio/ago. 2019 \\ DOI: http://dx.doi.org/10.7867/1981-9943.2019v13n2p289-300}

Portuguese Te deixo o último biscoito may be literally translated as I leave you the last cookie, but it sounds more appropriate if translated as You can have the last cookie.

Following, Equivalence: maintains the same situation in both languages, even using different grammatical structures; in other words, whenever a linguistic approach is no longer suitable to carry out a translation, the translator can rely on other procedures such as loantranslations, neologisms, idioms, metaphors, etc. The translation of proverbs is an example. Finally, Adaptation: modifies the translation to create a version of the text according to the cultural context of either language. For example, names of foods may sometimes undergo adaptations, because food is intrinsically a cultural concept. It is important to state that, according to Vinay and Darbelnet several of these processes may occur within the translation of a same sentence.

\subsection{PHRASAL VERBS IN THE ENGLISH LANGUAGE}

Phrasal Verbs are part of a larger category known as Multi-Word Verbs (BIBER et al 2010). Multi-Word verbs include also Prepositional Verbs, formed by a verb and a preposition, but, unlike phrasal verbs, the adding of the preposition does not change the meaning of the combination.

According to Eastwood (2005), a phrasal verb is a set consisting of a verb plus a prepositional or adverbial particle (e.g., in, down, off, up). A similar definition is brought by Harmer (1998, p.39): "[...] they are formed by adding an adverb or preposition (or adverb and a preposition) to a verb to create new meanings".

Cowan (2008, p. 171) categorizes phrasal verbs in two types: "transitive phrasal verbs" and "intransitive phrasal verbs". He explains that transitive phrasal verbs need an object and have the possibility to change position within the sentence. When change of position occurs, it is named a "particle movement rule". Cowan shows the example below, where it is possible to observe that the particle "up" goes to the end of the clause without changing the meaning.

a. Maggie looks up the address.

b. Maggie looks the address up. 


\section{Linguagens - Revista de Letras, Artes e Comunicação - ISSN 1981-9943 \\ Blumenau, v. 13, n. 2, p. 289-300, maio/ago. 2019 \\ DOI: http://dx.doi.org/10.7867/1981-9943.2019v13n2p289-300}

On the other hand, Intransitive phrasal verbs do not need an object. An example is "The plane took off". Cowan $(2008$, p. 173) calls the case in this example as a "pure intransitive phrasal verb" category because the adverb cannot be separated from the verb.

\subsection{HOW THE SUBTITLING PROCESS OCCURS}

According to Nobre (2002), for the subtitling process to be performed, it is necessary to follow a few steps. The first thing to do is to compare the original script with the target language and do the transcription of the lines. Then, it is necessary to mark how long each speech lasts. After marking the time, the composition of the subtitles is made and they are inserted inside the film or series. When everything is approved by the client, the subtitles will finally be recorded over the film or series.

Luyken (1991) and Nobre (2002) also describe some responsibilities attributed to the subtitle translator: 1) Taking the context into account while translating one language to another; Gorovitz (2006) points out that the translator should be loyal both to a will and to the expectations of its recipients; 2) Transcribing a text from oral to written, remembering that this text does not have the approval of the author (GOROVITZ, 2006); 3) Creating subtitles accounting for the necessity of a textual reduction due to the time as well as the number of characters allowed, the addition or removal of information, the font and size to be used for the subtitles.

\section{METHODOLOGY}

Before conducting an analysis regarding whether the phrasal verbs present in the episodes are translated literally from English to Portuguese or if they convey other meanings, the first step is recognizing which phrasal verbs are present in Bewitched. For this, the AntConc program, a software used to analyze the corpus was used. It is compatible with txt. documents (text documents), HTML (Hypertext Markup Language) and XML (eXtensible Markup Language). This procedure is useful to detect expressions and similar words in a fast way because it is possible to open a whole folder and work inside it, in a specific file. The software is available free on the internet ${ }^{5}$.

The basis of method of the research study reported here lies in the use of Corpus Linguistics, defined by Sardinha (2004) as an exploration of language based on

\footnotetext{
${ }^{5}$ Available at http://www.laurenceanthony.net/software.html.
} 


\section{Linguagens - Revista de Letras, Artes e Comunicação - ISSN 1981-9943 \\ Blumenau, v. 13, n. 2, p. 289-300, maio/ago. 2019 \\ DOI: http://dx.doi.org/10.7867/1981-9943.2019v13n2p289-300}

evidence extracted from an electronic medium such as a computer. The author also explains that the study of the standards in Corpus Linguistics is done through visualizations of concordance lines. The concordance is formed by a search term and the verification of its standard application. It is considered standard all that is used in a language in a natural way.

Sixty-two episodes of the Bewitched series were used to perform the analysis of the phrasal verbs, being 36 scripts of the first season and other 26 scripts of the last season in Portuguese and in English. AntConc software was used for each one of the scripts, individually, and their data were entered into 62 tables, one for each episode.

From the data found, the table created for each episode contains a column with the phrasal verb found from the software; a second column, with the meaning of the verb phrasal searched for phrasal verbs dictionaries one by one, manually; in the third, its official literal translation in Portuguese, based on bilingual dictionaries (English-Portuguese) and the websites Word Reference ${ }^{6}$ and Cambridge Dictionary ${ }^{7}$; and in the last column, as it was translated to subtitling (in this case, it was done manually too, reading the scripts in Portuguese and reading the scripts in English to find the same event and notice the differences among them). The objective of these tables is to compare the data in English and Portuguese and investigate how the translation is presented.

The particles searched for in AntConc were up, off and away. They were chosen because tests conducted with the software showed that these were the particles more frequently used in the original dialogues. After that, a second document in Excel was created to separate the original script with each phrasal verb in English, its context and its translation to Portuguese. A first column was created to represent the number of the episode; the second, the phrasal verbs found by AntConc; the third, the clauses or phrases with the context of the phrasal verb selected to be analyzed, and the last one the same context translated in Portuguese. A sheet was created for the first season and another one for the last season.

\section{ANALYSES OF THE PHRASAL VERBS FOUND}

The analysis of the phrasal verbs found take into account the processes described by Vinay and Darbelnet (1989; 2004): transposition, modulation, equivalence and adaptation. According to Kövecses (2003, p.6), metaphors are "[...] extremely simplified words, but it is exactly the simplified nature of these words that enables us to make use of parts of it in

\footnotetext{
${ }^{6}$ Available at https://www.wordreference.com/.

${ }^{7}$ Available at http://dictionary.cambridge.org/pt/dicionario/ingles-portugues.
} 


\section{Linguagens - Revista de Letras, Artes e Comunicação - ISSN 1981-9943 \\ Blumenau, v. 13, n. 2, p. 289-300, maio/ago. 2019 \\ DOI: http://dx.doi.org/10.7867/1981-9943.2019v13n2p289-300}

creating more abstract ones". Some emotions, for example, are also better understood through metaphors because, sometimes, there is not a word that sums up that situation in which the person is living. Because of that, she or he uses metaphorical expressions. The phrasal verbs turn off, get off and tie up occur in the corpus in a metaphorical way, being translated using the Equivalence and Modulation processes, respectively.

Let us regard the following examples taken from the series:

(1) Why don't you turn off the Kravitzs' door until we check it for shorts?

Desligue a porta dos Kravitz para que a gente a cheque.

(2) Whatever Serena turned on, I am gonna turn off.

Vou apagar qualquer chama que Serena tenha acendido.

\section{(3) You ready? I am just waiting for you to get it off your chest.}

Está pronto? Estou só esperando que você fale.

(4) I'm afraid Mr. Stephens is tied up.

O Sr. Stephens está ocupado.

In (1), we can observe that the phrasal verb has been translated literally, that is, according to the signified, switch off. However, if we look at the meaning of the translation applied in (2) we will see that the idea of switch off is used as erase, in the sense of the person named Serena has started some confusion that should soon be controlled. The metaphor here was used as a representation of what is being said and assists in the result of the conversation that would involve romantic feelings. In Portuguese, a word for romantic feelings is "flame". If this word had been applied literally, the correct word to remove the flames would be the word "apagar" in this target language.

In (3), the phrasal verb "get off" is combined with "your chest" forming an idiomatic expression in the English language. This idiomatic expression is metaphorical, using the image of 'removing' something from your chest to externalize an idea or thought. However, the metaphor is not carried into the target language, and the translator chose to modulate the expression into something more appropriate in Portuguese.

Another phrasal verb, tied up (example 4), has suffered modulation in the translation. In the English language, it is a metaphor in which the idea is to represent that Mr. Stephens is 


\section{Linguagens - Revista de Letras, Artes e Comunicação - ISSN 1981-9943 \\ Blumenau, v. 13, n. 2, p. 289-300, maio/ago. 2019 \\ DOI: http://dx.doi.org/10.7867/1981-9943.2019v13n2p289-300}

really occupied with doing another thing and the translation of the metaphor "amarrado" would be a possibility for Portuguese speakers. However, it would not fit the formality of the situation expressed by the contextualization of the politeness marker 'I'm afraid'.

The phrasal verb pick up appears to have undergone some different translation processes in the series subtitling. Examples 5, 6 and 7 illustrate that the metaphorical meaning of pick up was used in the original, not the literal meaning of "lifting from the ground". The translation in example 5 uses literal/direct translation; the translation of example 6 makes use of the Equivalence process, using the rhetoric figure known as metonymy.

\section{(5) I'll pick you up at the office at [...]}

Eu o pegarei no escritório às [...]

(6) One of the cars will pick him up.

Uma das viaturas vai achá-lo.

(7) Where can we pick you up?

Onde vamos buscá-las?

In example $(7$,$) the translation undergoes the process of Modulation, since if using the$ verb that was used in example (5) ("pegá-las") the idea of the sentence would change. The verb "buscar" in Portuguese entails the idea of picking someone up using a vehicle, which was what the characters were going to do in the context.

Another noticeable feature is that in all these examples (5-7) the phrasal verbs were translated in a diachronic way, to reflect how people spoke in the 1960s. Back then, people had the habit of conjugating Portuguese verbs correctly using the object pronouns more formally. This accounts for the use of the Transposition process in the three examples.

Another process that appears to be used in the translation of some phrasal verbs in the scripts of the series is the Adaptation. Examples 8 and 9 illustrate the use of the phrasal verb give up:

(8) I love you, and I can't give you up.

Eu a amo e não vou perdê-la.

(9) You mean you're willing to give him up? Well, you could put it that way.

Quer dizer que está disposta a abrir mão dele? Bem pode-se dizer assim. 


\section{Linguagens - Revista de Letras, Artes e Comunicação - ISSN 1981-9943 \\ Blumenau, v. 13, n. 2, p. 289-300, maio/ago. 2019 \\ DOI: http://dx.doi.org/10.7867/1981-9943.2019v13n2p289-300}

The original meaning of the phrasal verb give up is to stop doing or having something. In example (8), the Adaptation process used the concept of "losing" someone, a collocation very commonly used in the culture of Brazilian Portuguese when speaking about breaking a romantic relationship. Just as in examples (5), (6) and (7) the pronoun "-la" adapts to the time the series was produced. In the current days it may have been translated into "perder você". The use of the pronoun in the Portuguese version also signals that the Transposition process has been used by the translator.

Example (9) refers to the adaptation process in which the original has been translated into a more updated version, using an idiomatic expression in the target language. One translation that could have been used would be "desistir", but the translator decided to use “abrir mão", probably better suited for the situation.

Another example of a phrasal verb that can be found metaphorically is go away (example 10). The usual meaning of it is to leave; to run away.

\section{(10) I promise you it won't (?) go away.}

Juro que ela não sumirá.

In this part of the conversation, Samantha and James talk about being late to visit the Tower of London ("it" refers to the tower). To keep the idea of the comic part of the scene the translators chose to translate as " it will not disappear"; the adaptation of the translation into Portuguese carried the intrinsic meaning of "sumir" in Portuguese, which has a definite idea of disappearing for good.

Translations are created thinking about the meaning and the feeling of the message. In the case of example 11, we have the literal meaning for tapper off, that, in Portuguese, is "se estabilizar". But, sometimes, this expression is more formal than informal. Because the scene was more informal, the translators adapted another idea for this phrasal verb, using the Transposition process.

\section{(11) Maybe I can tapper off.}

Vou me adaptando aos pouquinhos.

This was a way for people who were watching to get acquainted with the scene and at the same time be able to experience what was happening and feel what the character was trying to get across with the expression. Here is also a case of the Adaptation process, using a 


\section{Linguagens - Revista de Letras, Artes e Comunicação - ISSN 1981-9943 \\ Blumenau, v. 13, n. 2, p. 289-300, maio/ago. 2019 \\ DOI: http://dx.doi.org/10.7867/1981-9943.2019v13n2p289-300}

diminutive expression " aos pouquinhos", which means little by little, so that the informal tone could be achieved.

The phrasal verb hurry up, in example 12, is another instance of Transposition. The translator chose to use a different word class to express the meaning of the phrasal verb, an adverb of time instead ("logo" means "soon").

(12) Well, get rid of him! And hurry up, it's cold in here.

\section{Livre-se logo dele! Está frio aqui.}

The Phrasal Verbs before analyzed are a good instance of what Oustinoff (2011) predicted about the necessity of speeches to be reformulated for a better understanding in the target language. The processes described by Vinay and Darbelnet $(1989,2004)$ were present in the occurrence of these multiword constructions, playing an important role in the quality of the subtitling presented to the audience; as well, it is a possibility that the processes were also applied so that the subtitles would fit not only the meaning intended but also the time frame the subtitles feature.

\section{CONCLUSION}

This article reports a study of phrasal verbs found in the TV series Bewitched, examining how the translation of English phrasal verbs in the first and the last season of the series Bewitched has been featured to the target language in Portuguese. The methodology used to search for the phrasal verbs was a Corpus Linguistics tool, AntConc, and the scripts of the first and the last season were used. The phrasal verbs with the particles up, off, and away were chosen following the frequency criteria.

The results of this study confirm that the phrasal verbs were not translated literally from the English Script into the Portuguese subtitles, but could be analyzed into what Vinay and Darbelnet $(1989 ; 2004)$ call Oblique Translation processes: adaptation, modulation, equivalence and transposition.

It is believed that this work contributes to the area by making people aware of the process of subtitling for the Portuguese language, as well as for any other language, that is much more complex than one imagines and that it surely requires a deep analysis. 


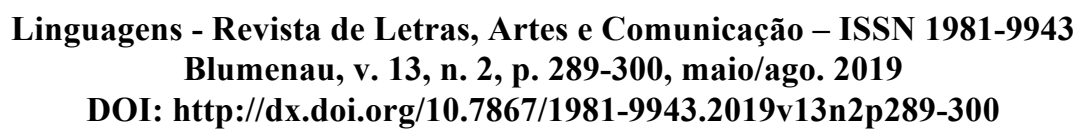

Further developments of this study could analyze the translation of all phrasal verbs in the series script, to check if the processes are being used instead of the literal translation, characterizing the subtitling process of this series more thoroughly.

\section{REFERENCES}

ANTHONY, Laurence. AntConc: A Learner and Classroom Friendly, Multi-Platform Corpus Analysis Toolkit. Proceedings of IWLeL 2004: An Interactive Workshop on Language eLearning. Disponível em:

http://www.laurenceanthony.net/research/iwlel_2004_anthony_antconc.pdf. Acesso em: abr. 2020.

BARBOSA, Heloísa Gonçalves. Procedimentos técnicos da tradução: uma nova proposta. São Paulo: Pontes, 1990.

BIBER, D. et al. Longman Grammar of Spoken and Written English. Harlow, Essex: Pearson Education, 2010.

CAMPOS, Geir. O que é tradução. São Paulo: Brasiliense, 1986.

CAPPELLE, Bert. LOOCK, Rudy. Typological differences shining through: The case of phrasal verbs in translated English. In: DE SUTTER, Gert. LEFER, Marie-Aude. DELAERE, Isabelle. Empirical Translation Studies: New Theoretical and Methodological Traditions, Mouton de Gruyter, 2017. pp. 235-264.

COWAN, Ron. The Teacher's Grammar of English: a course book and reference guide. New York: Cambridge University, 2008.

DEWI SATYA UTAMI, Ni Made. Phrasal Verbs Found In the Movie "Finding Dory" and Their Translations Into Indonesian. Humanis, [S.1.], v. 22, n. 2, p. 509-515, may 2018. ISSN 2302-920X. Available at: <https://ojs.unud.ac.id/index.php/sastra/article/view/39793>. Access in: apr. 2020.

EASTWOOD, John. Oxford Learner's Grammar. Oxford: Oxford University, 2005.

GOROVITZ, Sabine. Os labirintos da tradução: A legendagem cinematográfica e a construção do imaginário. Brasília: Universidade de Brasília, 2006.

HARMER, Jeremy. How to teach English: an introduction to the practice of English language teaching. Edinburgh Gate: Longman, 1998.

HASHEMI, Mahmood. AREZI, Atefeh. A Study of Applied Strategies in Translating Idiomatic Expressions in Two Movie Subtitles: Bring It On \& Mean Girls. IJRELT, v. 3, n. 2, p. 80-93, 2015.

KÖVECSES, Zoltán. Metaphor: A Practical Introduction. Oxford: Oxford University, 2003. 
LUYKEN, G.M. et al. Overcoming language Barriers in Television. Dubbing and Subtitling for the European Audience. Manchester, The European Institute for the Media, 1991.

MORAES, Isadora T. Subtitling of collocational patterns in children's animated movies: a corpus-based study. Dissertação (mestrado) - Universidade Federal de Santa Catarina, Centro de Comunicação e Expressão, Programa de Pós-Graduação em Inglês: Estudos Linguísticos e Literários, Florianópolis, 2015. Available at: https://repositorio.ufsc.br/handle/123456789/135996. Access in: apr. 2020.

NOBRE, Antonia Célia Ribeiro. A influência do ambiente audiovisual na legendação de filmes. Rev. bras. linguist. apl. [online], vol. 2, n. 2., 2002. Available in: http://www.scielo.br/pdf/rbla/v2n2/04.pdf. Access in: apr. 2020.

OUSTINOFF, Michael. Tradução: História, teorias e métodos. São Paulo: Parábola, 2011.

SARDINHA, Tony Berber. Linguística de Corpus. Barueri, SP: Manole, 2004. 410 p.

VINAY, Jean-Paul; DARBELNET Jean. Translation procedures. Readings in Translation Theory. Ed. A. Chesterman. Loimaa: Finn Lectura, 1989.

. A Methodology for Translation. In: VENUCI, Lawrence (ed.) The Translation Studies Reader. London and New York: Routledge, 2004. p. 84-93.

TALMY, Leonard. Path to realization: a typology of event conflation. Berkeley Linguistics Society (BLS), 17, p. 480-519, 1991.

Towards a cognitive semantics. Typology and process in concept structuring. Cambridge, MA: MIT Press, 2000.

VALENTINI, Cristina. Phrasal verbs in Italian dubbed dialogues: a multimedia corpus-based study. Perspectives: Studies in Translation Theory and Practice, v. 21, n. 4, p. 543-562, 2013 . 